\title{
Vegetation Stagnation in Three-Phase Big Game Exclosures
}

\author{
PAUL T. TUELLER AND JERALD D. TOWER
}

\begin{abstract}
The allocation of range forage for deer and livestock is an important range management problem. Utilization of the threephase exclosure technique for such evaluations is complicated by the response of plants to nonuse. Protection from browsing can cause "stagnation" to occur as early as the second year after the exclosure is established. Nonuse of bitterbush resulted in an average reduction in production of $70 \%$. Temporary exclosures moved each year are required for accurately determining annual forage production.
\end{abstract}

Resource managers lack methods that will give reliable estimates of site productivity and its relationship to carrying capacity for either livestock or big game. One procedure often followed for partitioning forage has been the use of three-phase exclosures.

This paper reports a 6 year study to determine site productivity (i.e.. pounds of vegetation produced per hectare) through the use of three-phase exclosures and temporarily erected movable exclosures. Production refers to the total annual dry matter increment of grasses, forbs, and browse. Effects of different species, plant density and dispersion characteristics. vegetation stagnation caused by lack of grazing, and site differences within three-phase exclosure all tend to confound range production and utilization data. Factors considered to influence these results are precipitation, past utilization, condition and trend of the vegetation, and the period of protection from grazing. Stagnation can be defined as the

The atuhors are prolessor of range ecology and graduate fellow. University of Nevada Reno. lower is nou Range Conservationist. U.S. Forest Service. Phoenix. Arizona.

the atthors wish to recognize the funding assistance given by the Bureau of Land Management and the Nevikda Fish and Game Department. who also constructed the exclesures. This report is a contribution of the Nevada Agricultural Experiment Station. lommal Series Number +17

Mamuscript received Maty 17.1978. reduction in productivity of range plants resulting from a lack of grazing.

Use of exclosures for rangeland evaluation has received wide acceptance. Daubenmire (1940) defined the exclosure as any experimental area which is protected from the activities of a particular class of animal by a barrier such as a fence or screen. They have some drawbacks, such as the barrier effect which will influence wind movement, precipitation, and seed collection. Three-phase exclosures were used as early as 1932, to discover and demonstrate the food preferences of animals (Young 1955). Each phase should be 1 acre (.405 hectare) or larger to have the least effect on the probability that deer will enter and should be located so that all phases are located on a single vegetatively homogeneous and representative part of the rangeland (Young 1958). Jones (1965) and McMahon (1966) have used the exclosure technique to study relative utilization, cover and compositional changes, and other effects.

\section{Methods}

Four important Nevada deer ranges and corresponding exclosure sites were selected for this study. Paine Springs, White Rock, Morey Bench, and the Fort Ruby sites were selected on the basis of vegetal homogeneity among exclosure phases and because they represent important deer winter range habitat-types.

The Paine Springs exclosure, built in 1962, is located in the Duck Creck Basin, near McGill in White Pine County within an Artemisia tridentata/Purshia tridentata/Poa secunda plant community at 2,073m elevation. The White Rock exclosure, near White Rock Peak in Lincoln County, is situated in an Artemisia tridentata/Purshia tridentata/Poa secunda plant community at approximately 2,190-m elevation and was constructed in 1965. Morey Bench is in Hot Creek Valley east of Tonopah in Nye County. A three-phase exclosure was built there in 1965 situated in an Artemisia tridentata/Purshia glandulosa/Prunus andersonii plant community at the base of Morey 


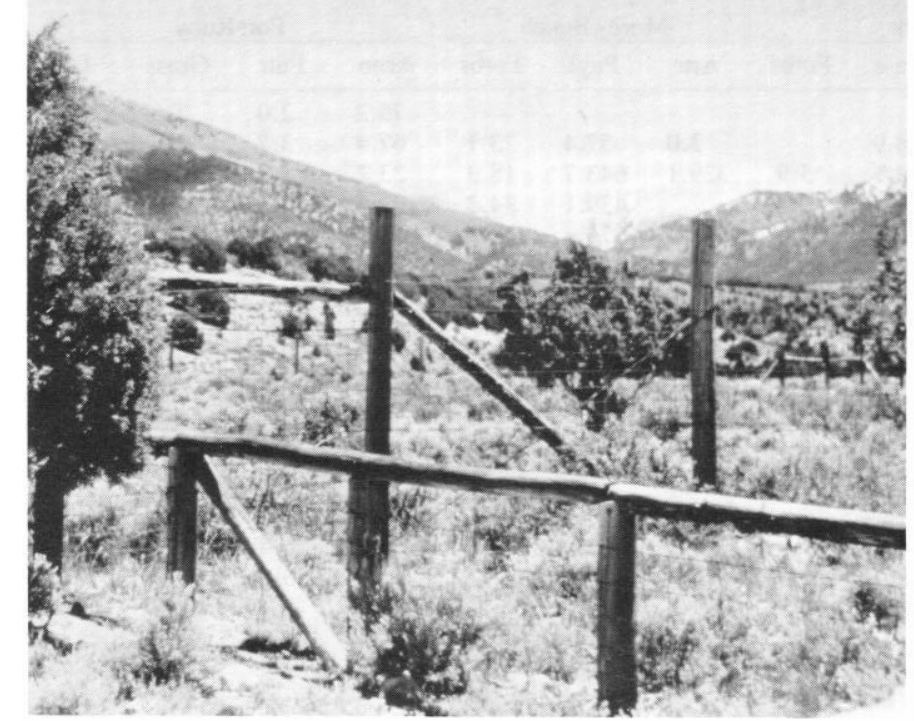

Fig. 1. The Three-Phase Exclosure: Phase A (high fence) and Phase B (low fence).

Peak $(2,072 \mathrm{~m})$. The Fort Ruby exclosure, constructed in 1959, is located at 1,920 m elevation just south of the Ruby Marshes in White Pine County. The boundaries of the latter exclosure encompass an ecotone comprised of the Pinus monophylla/Juniperus osteospermal/ Artemisia nova and the Artemisia nova/Chrysothamnus viscidiflorus/ Purshia tridentata plant communities.

All exclosure areas consist of three phases (Fig. 1), each encompassing .405 hectares ( 1 acre): one phase is fenced to exclude all foraging (Phase A); a second fence excludes livestock but allows deer foraging (Phase B); the third is unfenced and allows both livestock and deer foraging (Phase $\mathrm{C}$ ). The following assumptions are made: highest production, a measure of site potential, is achieved in Phase A; deer utilization is represented by the difference in production between Phase $\mathrm{A}$ and Phase $\mathrm{B}$ following the foraging season; livestock utilization is derived from Phase B production after grazing less Phase $\mathrm{C}$ production after grazing.

Vegetation at each site was originally described using a modification of the method described by Poulton and Tisdale (1961) including cover and density. Ten transects each of ten contiguous frequency quadrats were employed to determine frequency. Twentyor 30 -inch $(50.8$ or $76.2 \mathrm{~cm}$ ) square quadrats were used. During the summer of 1969, cover data were obtained from individual clip plots of both temporary and permanent exclosures. Height in meters to the highest point and density measurements of selected shrub species were taken within the $20 \mathrm{ft}$ by $20 \mathrm{ft}(6.1 \times 6.1 \mathrm{~m})$ clip plots.

\section{Annual Forage Production}

Production data were obtained by the clip before-and-after method. Bitterbrush was clipped on plots $20 \mathrm{ft}$ by $20 \mathrm{ft}(6.1 \times 6.1 \mathrm{~m})$. Sagebrush and other shrub species were clipped from a $10 \mathrm{ft}$ by $10 \mathrm{ft}$ $(3.05 \times 3.05 \mathrm{~m})$ plot, and production of grasses and forbs was determined by clipping a plot $4 \mathrm{ft}$ by $12 \mathrm{ft}$. Both latter plots were nested within the larger plot. Five $20 \mathrm{ft}$ by $20 \mathrm{ft}(6.1 \times 6.1 \mathrm{~m})$ clip plots were located at random from among the total of 100 in each phase. By restricting the randomization, new plots were clipped each year.

Grasses and forbs were clipped at ground level. Bitterbrush and serviceberry were clipped of all current year's twig growth. On sagebrush current annual growth is difficult to determine. Therefore, new shoot length was estimated before being clipped. Data represent total annual vegetative yield and not necessarily available forage. However, it is felt that all material clipped in this study was available to the grazing animal. Clippings were oven dried at $70^{\circ}$ for $48 \mathrm{hr}$, weighed, and the weights converted to kilograms/hectare.
Five temporary exclosures square in shape, each encompassing an area of $400 \mathrm{ft}^{2}\left(37.16 \mathrm{~m}^{2}\right)$, were located within Phase $\mathrm{C}$ at each exclosure site during the summer of 1968. Five older temporary exclosures of the same dimensions were erected at the Paine Springs and Morey Bench sites in the summer of 1966.

The temporary exclosures were used to supply a better estimate of site potential than that obtained from Phase $\mathrm{A}$, or the continuously protected area. They provide protection from grazing for one growing season only, and were moved each year. Total annual production was measured on the vegetation within these structures and compared to that taken from Phase A. By this comparison the effect of stagnation can be quantified.

Employment of the temporary exclosure technique makes possible the assessment of the effects of stimulation provided by grazing on forage production. This technique eliminates the influence due to "stagnation" and gives a better estimate of the annual potential production of a particular site.

Shrub yields were corrected on the basis of volume-of-area occupied per species in an effort to overcome the problems of vegetation heterogeneity among phases. Harniss and Murray (1976) have shown that the dry leaf weight production of sagebrush can be estimated from height and circumference measurements. Their literature review showed that shrub production can be related to crown diameter, stem diameter, foliage cover and basal area and known volume. Similar relationships held true for certain grasses (Pasto et al. 1957; Evans and Jones 1958; Frakes 1959; Reppert 1962; Payne 1974; Uresk et al. 1977).

A multiple linear correlation analysis was used to test the relation of cover, height and density to yield. The relation of each sampled parameter to yield was determined for sagebrush and bitterbrush taken from each sample plot. If the correlations were found to be significant, the standard partial regression coefficients were computed and used as measures of the relative importance of each independent variable on yield. In this manner, a weighted index using the standard partial regression coefficients of each independent variable can be used to correct the yield data of each phase of the exclosure to that recorded from the temporaries. This constitutes a correction to a level of production that could be expected if stagnation had not been a factor.

The formula derived to correct yields of the various exclosure phases to that taken from the temporaries is:

\section{Estimation of Deer Use}

Relative deer use among the exclosure phases was tested (a $t$-test for paired plots) by comparing counts taken from each phase of the exclosure system. Pellet groups were counted in ten 0.01 -acre $(0.004$ ha) plots in each phase. These values were divided by 13 , the average pellet groups/day/deer, in order to convert the data to deer-days use per acre (Smith 1964). Counts were not significantly different at the 0.05 level of probability, and deer use between Phase C and Phase B was considered equal.

\section{Results}

The protected areas must produce the same quantity as the browsed and grazed vegetation if the three-phase exclosure is to provide information on deer-livestock competition as computed from differences in utilization. Data from our four study sites show that the effect of vegetation stagnation precludes this capability

\section{Paine Springs}

Production data (Table 1) were too variable for any conclusions concerning deer-livestock competition or for comparisons of the vegetation production among exclosure phases. However, the erection of temporary exclosures provided data on total vegetation production. Cover, height and density were significantly related to the corresponding yield of bitterbrush in simple and multiple linear regression analysis (Table 2). The standard partial regression coefficients have been weighted 
Table 1. Yields expressed in kilograms/hectare of oven-dry forage at four study sites.

\begin{tabular}{|c|c|c|c|c|c|c|c|c|c|c|c|c|c|c|c|c|}
\hline \multirow{2}{*}{$\begin{array}{l}\text { Study } \\
\text { site } \\
\text { Phase }\end{array}$} & \multicolumn{5}{|c|}{ Paine Springs } & \multicolumn{4}{|c|}{ White Rock } & \multicolumn{3}{|c|}{ Morey Bench } & \multicolumn{4}{|c|}{ Fort Ruby } \\
\hline & Year & Artr & Putr & Grass & Forbs & Artr & Putr & Grass & Forbs & Artr & Pugl & Forbs & Arno & Putr & Grass & Forbs \\
\hline \multirow[t]{6}{*}{ A } & 1964 & 101.5 & 54.0 & 74.0 & & & & & & & & & 75.2 & 2.0 & 3.6 & \\
\hline & 1965 & 112.3 & 37.8 & 91.5 & & 239.2 & 69.6 & 48.9 & & 3.0 & 57.4 & 23.1 & 67.4 & 3.7 & 7.2 & \\
\hline & 1966 & 46.7 & 1.2 & 140.8 & 11.2 & 79.5 & 63.9 & 52.5 & 5.9 & 329.1 & 643.7 & 18.3 & 23.2 & 2.9 & 10.3 & 5.8 \\
\hline & 1967 & 402.3 & 56.1 & 129.2 & 11.5 & 371.1 & 52.5 & 37.7 & 50.2 & & 439.1 & 34.2 & 102.4 & 5.1 & 26.9 & 57.4 \\
\hline & 1968 & 78.1 & 11.1 & 191.4 & 7.9 & 73.2 & 10.1 & 216.4 & & & 176.4 & & 39.0 & 2.4 & 33.4 & 23.6 \\
\hline & 1969 & 157.4 & 16.1 & 167.2 & 22.6 & 436.2 & 52.5 & 79.5 & 14.9 & & 8.2 & & 96.3 & & 91.5 & 100.3 \\
\hline \multirow[t]{6}{*}{ B } & 1964 & 85.9 & 38.4 & 79.4 & & & & & & & & & 48.2 & 1.7 & 5.8 & \\
\hline & 1965 & 41.4 & 66.1 & 139.9 & & 223.6 & 36.9 & 40.9 & & 8.4 & 33.7 & & 58.6 & 0.7 & 13.4 & \\
\hline & 1966 & 65.4 & 5.7 & 45.4 & 2.6 & 299.8 & 33.5 & 41.4 & 14.5 & 32.7 & 569.6 & 10.8 & 101.2 & 3.9 & 7.1 & \\
\hline & 1967 & 63.9 & 53.9 & 123.3 & 16.7 & 324.1 & 106.5 & 52.2 & 19.7 & & 611.5 & & 94.9 & 14.9 & 31.9 & 88.9 \\
\hline & 1968 & 136.7 & 30.1 & 174.3 & 0.6 & 231.2 & 18.3 & 27.2 & & & 204.2 & & 73.9 & 1.1 & 23.8 & 1.6 \\
\hline & 1969 & 173.8 & 8.7 & 117.4 & 2.4 & 478.3 & 114.3 & 73.2 & & & 29.9 & & 191.4 & 6.0 & 36.8 & \\
\hline \multirow[t]{6}{*}{$\mathrm{C}$} & 1964 & 97.6 & 11.2 & 36.7 & & & & & & & & & 52.1 & 0.3 & 0.9 & \\
\hline & 1965 & 110.3 & 17.3 & 36.4 & & 157.3 & 22.2 & 44.4 & & 8.0 & 13.4 & & 24.7 & 0.4 & 6.3 & \\
\hline & 1966 & 32.3 & 4.5 & 19.7 & 3.0 & 115.7 & 19.2 & 18.9 & 10.0 & 15.7 & 394.5 & & 46.7 & 3.8 & 2.6 & 2.6 \\
\hline & 1967 & 137.6 & 90.8 & 102.6 & 30.5 & 234.4 & 121.3 & 42.5 & 18.9 & & 592.7 & & 193.6 & 3.6 & 28.7 & 4.9 \\
\hline & 1968 & 84.2 & 28.6 & 53.9 & 1.6 & 222.4 & 10.8 & 25.0 & & & 135.6 & & 99.4 & 1.9 & 0.6 & \\
\hline & 1969 & 140.2 & 18.9 & 62.7 & 5.9 & 396.1 & 83.9 & 33.6 & & & 21.0 & & & & & \\
\hline \multirow{3}{*}{$\begin{array}{l}\text { Old } \\
\text { temp- } \\
\text { oraries }\end{array}$} & 1967 & 284.1 & 105.7 & 98.6 & 13.8 & & & & & & 426.3 & 89.7 & & & & \\
\hline & 1968 & 81.1 & 84.5 & 244.9 & 55.3 & & & & & & 26.2 & & & & & \\
\hline & 1969 & 208.6 & 102.9 & 181.7 & 11.2 & & & & & & 31.4 & & & & & \\
\hline $\begin{array}{l}\text { New } \\
\text { temp- } \\
\text { ories }\end{array}$ & 1969 & 277.8 & 40.8 & 110.7 & 17.9 & 450.9 & 181.4 & 88.1 & 1.0 & & 97.4 & & 432.1 & 6.9 & 49.2 & 20.7 \\
\hline
\end{tabular}

\footnotetext{
Artr - Artemisia tridentata

Arno-Artemisia nova

Putr - Parshia tridentata

Pugl - Purshia glandulosa
}

$44.1 \%$ for cover, $26.1 \%$ for height, and $29.8 \%$ for density.

For the 1969-1970 period, potential production of bitterbush in the temporary exclosures was $40.8 \mathrm{~kg} / \mathrm{ha}$ while yield from the completely protected area was only $16.1 \mathrm{~kg} / \mathrm{ha}$. Hence, Phase A produced only $39 \%$ of its potential in 1969 , and stagnation has accounted for a $61 \%$ reduction in production following protection for 8 years. A correction of yield in the A phase based on the weighted index shows that without the effect of stagnation the production of bitterbrush based on cover, density, and average height of plants should have been $41.56 \mathrm{~kg} / \mathrm{ha}$.

Cover percentages of Artemisia tridentata from the temporary exclosures and Phase A were $10.43 \%$ and $10.94 \%$, respectively (Table 3 ). However, sagebrush in Phase $A$ has produced only $59 \%$ of that recorded from the temporaries. For rabbitbrush (Chrysothamnus viscidiflorus), the temporaries produced approximately one-third of that recorded in Phase A. For grasses, the results were variable. The old temporaries had higher yields in 1968 and 1969 but not in 1967. This is explained in part by the effect protection from grazing has on plants previously subjected to heavy utilization. Although basal cover estimates for grasses were approximately equal, yield was greater in plots protected for 8 years. Perhaps the stagnating effect expressed by shrubby species allows for a "release" of previously suppressed grass species so that growth and subsequent yield are increased. Data from the control plots (Phase C) indicate that stagnation has, indeed, occurred for shrubs. Shrub species show a large reduction in productivity as a result of continued protection from grazing. Whenever the $\mathrm{B}$ or $\mathrm{C}$ phase outproduces the A phase, some irregularity in the technique is indicated. On the other hand, grasses and forbs show a definite increase in total forage produced due to protection from grazing, even though production outside is greater during a good year. These data suggest that the area is not presently being grazed at its potential. Yield figures from two different sets of temporary exclosures show potential forage production from all plants to be greater than $448 \mathrm{~kg} / \mathrm{ha}$ of oven dry forage.

Comparisons of the data obtained from the temporary and existing exclosures indicate that protection from grazing has caused a sizable reduction in the amount of browse production. Both bitterbrush and sagebrush were at a static low level of production due to the lack of utilization. Results from the old temporary exclosures show that $100 \%$ simulated utilization for those two species over 3 years, a measure of site productivity, produced yields that were greater than from those plants receiving "normal" grazing at the Paine Springs site. This suggests that the "normal" grazing patterns were not sufficient to provide the annual grazing stimulus required to give optimum browse production at some judicious utilization rate.

\section{White Rock}

Initial results appeared favorable for the prediction of the relative use by wildlife and livestock for bitterbrush and sagebrush (Table 1). However, the effects of stagnation were obvious after less than 2 years.

The standard partial regression coefficients calculated from the analysis of cover, height and density (Table 2) were rated $39.94 \%, 19.76 \%$, and $42.30 \%$, respectively. Phase A could have produced $172.6 \mathrm{~kg} / \mathrm{ha}$ of bitterbrush under similar treatment and is comparable to the site potential obtained from the temporaries, where $181.4 \mathrm{~kg} / \mathrm{ha}$ of bitterbrush was recorded. Stagnation is thought to be responsible for the phase A production of only $52.5 \mathrm{~kg} / \mathrm{ha}$ of bitterbrush, or $30 \%$ of its potential. Stagnation has accounted for a $70 \%$ reduction in production from site potential after 5 years of continued protection from the annual stimulus of grazing.

Stagnation caused less reduction in sagebrush production. Cover percentages for sagebrush show that the A phase and the 
Table 2. Simple and multiple linear correlations of vegetative parameters from bitterbrush at four study sites.

\begin{tabular}{|c|c|c|c|c|c|c|c|c|c|c|c|}
\hline \multicolumn{4}{|c|}{ Variables } & \multicolumn{2}{|c|}{ Paine Springs } & \multicolumn{2}{|c|}{ White Rock } & \multicolumn{2}{|c|}{ Morey Bench } & \multicolumn{2}{|c|}{ Fort Ruby } \\
\hline $\begin{array}{l}X_{1} \\
C\end{array}$ & $X_{2}$ & $\mathrm{X}_{3}$ & Yield ${ }^{Y}$ & $\begin{array}{c}\mathrm{r} \\
919^{b}\end{array}$ & $\begin{array}{l}\mathbf{r}^{2} \\
845\end{array}$ & $\begin{array}{c}\mathrm{r} \\
.816^{b}\end{array}$ & $\begin{array}{l}r^{2} \\
666\end{array}$ & $\begin{array}{c}\mathrm{r} \\
.878^{b}\end{array}$ & $\begin{array}{c}r^{2} \\
771\end{array}$ & $\begin{array}{c}r \\
841^{b}\end{array}$ & $\begin{array}{l}r^{2} \\
707\end{array}$ \\
\hline $\mathrm{H}$ & & & $\begin{array}{l}\text { Yeld } \\
\text { Yield }\end{array}$ & -.778 & .605 & .467 & .218 & -.246 & .058 & .196 & .038 \\
\hline D & & & Yield & $.890^{b}$ & .792 & $-.802^{b}$ & .643 & .654 & .428 & -.070 & .005 \\
\hline C & $\mathrm{H}$ & & Yield & $.974^{a}$ & .949 & $.816^{b}$ & .666 & $.878^{b}$ & .772 & $.869^{\circ}$ & .755 \\
\hline $\mathrm{C}$ & $\mathrm{D}$ & & Yield & $.930^{b}$ & .865 & $.878^{\prime \prime}$ & .771 & $.963^{a}$ & .928 & $.977^{a}$ & .954 \\
\hline $\mathrm{H}$ & $\mathrm{D}$ & & Yield & $.898^{b}$ & .806 & $.813^{b}$ & .661 & .665 & .442 & .206 & .042 \\
\hline$\overline{\mathrm{C}}$ & $\mathrm{H}$ & $\mathrm{D}$ & Yield & $.997^{a}$ & .994 & $.901^{a}$ & .812 & $.991^{n}$ & .982 & $.988^{a}$ & .977 \\
\hline
\end{tabular}

$\mathrm{C}=$ cover: $\mathrm{H}=$ height: $\mathrm{D}=$ density: $=$ significant at $.01: "$ = significant at $0.1 ; \mathrm{r}-$ regression coefficient: $\mathrm{r}^{2}=$ coefficient of determination

temporaries are almost equal. Yields from 1969 show production in Phase A to be slightly less $(436 \mathrm{~kg} / \mathrm{ha})$ than that taken from the temporary exclosures $(451 \mathrm{~kg} / \mathrm{ha})$ (Table 1). Likewise, differences between the temporaries and $\mathrm{B}$ and $\mathrm{C}$ phases of the exclosure show no statistical significance.

Grass in the A Phase had a greater cover percentage but a lower density than that recorded from the temporary exclosures. Yields for the 1969 season showed production to be approximately equal and only slightly higher in the temporary exclosures when compared to the $\mathrm{A}$ and $\mathrm{B}$ phases. Yield was much lower for the $\mathrm{C}$ phase, indicating that production was greater in the temporaries possibly due to vigor brought about by the first years of protection from grazing. Protection from grazing for one growth season and favorable growing condition appear to be responsible for the increase in production of the grasses previously subjected to heavy annual utilization by cattle at this site. Our test was not sensitive enough to predict the effect, if any, stagnation may have had on the grass inside the completely protected area.

The differences in forb yields appear to be simply a function of frequency of occurrence and cover precentages in each phase. Forb cover in the temporaries is barely more than a trace and frequency of occurrence is less than half that in the A phase (Table 3).

Protecting the vegetation for only one growing season accompanied by favorable precipitation showed that potential forage production at the White Rock exclosure can be much greater than the level of the production represented by the control area. The temporary exclosures produced approximately $721 \mathrm{~kg} / \mathrm{ha}$ of oven-dry vegetation during an average precipitation year (1969) and thus probably is a good representation of site potential.

\section{Morey Bench}

The Morey Bench exclosure was constructed in January of 1965 and the first year's production and utilization data yielded a computed $77 \%$ utilization of desert bitterbrush (Table 1). However, by 1967 stagnation was noticeable. Cover and height alone may not adequately weight the index for correcting the production yields (Table 3 ) at this site. The added influence of density in the computation of the correlation coefficients showed a higher level of significance than that recorded for cover times height on yicld. Therefore, density measurements from within the A phase the the temporary exclosures were used

Table 3. Vegetation parameters for sagebrush and bitterbrush on four Nevada deer range in 1969.

\begin{tabular}{|c|c|c|c|c|c|c|c|c|c|}
\hline \multirow{2}{*}{$\frac{\text { Study Site }}{\text { Parameter }}$} & \multirow[b]{2}{*}{ Phase } & \multicolumn{2}{|c|}{ Paine Springs } & \multicolumn{2}{|c|}{ White Rock } & \multicolumn{2}{|c|}{ Morey Bench } & \multicolumn{2}{|c|}{ Fort Ruby } \\
\hline & & Artr & Putr & Artr & Putr & Artr & Pugl & Arno & Putr \\
\hline $\begin{array}{l}\text { Cover } \\
\text { (percent) }\end{array}$ & $\begin{array}{c}\text { A } \\
\text { B } \\
\text { C } \\
\text { Tempo- } \\
\text { raries }\end{array}$ & $\begin{array}{l}10.94 \\
12.09 \\
10.46 \\
10.43\end{array}$ & $\begin{array}{r}10.87 \\
5.14 \\
10.24 \\
9.94\end{array}$ & $\begin{array}{l}15.45 \\
21.11 \\
14.19 \\
15.30\end{array}$ & $\begin{array}{r}10.31 \\
9.40 \\
9.49 \\
7.88\end{array}$ & $\begin{array}{l}6.57 \\
3.98 \\
4.51 \\
5.37\end{array}$ & $\begin{array}{l}16.20 \\
17.95 \\
14.01 \\
25.34\end{array}$ & $\begin{array}{l}11.04 \\
17.61 \\
16.02 \\
16.62\end{array}$ & $\begin{array}{l}0.91 \\
0.29 \\
0.62\end{array}$ \\
\hline $\begin{array}{l}\text { Frequency } \\
\text { (percent) }\end{array}$ & $\begin{array}{l}\mathrm{A} \\
\mathrm{B} \\
\mathrm{C}\end{array}$ & $\begin{array}{l}75 \\
61 \\
73\end{array}$ & $\begin{array}{l}20 \\
18 \\
15\end{array}$ & $\begin{array}{l}86 \\
76 \\
69\end{array}$ & $\begin{array}{l}36 \\
29 \\
50\end{array}$ & $\begin{array}{r}27 \\
23 \\
6\end{array}$ & $\begin{array}{l}35 \\
34 \\
27\end{array}$ & $\begin{array}{l}71 \\
74 \\
73\end{array}$ & $\begin{array}{r}3 \\
14 \\
4\end{array}$ \\
\hline $\begin{array}{l}\text { Height } \\
\text { (meters) }\end{array}$ & $\begin{array}{c}\mathrm{A} \\
\mathrm{B} \\
\mathrm{C} \\
\text { Tempo- } \\
\text { raries }\end{array}$ & & $\begin{array}{l}0.75 \\
0.72 \\
0.67 \\
0.64\end{array}$ & & $\begin{array}{l}0.54 \\
0.56 \\
0.32 \\
0.43\end{array}$ & & $\begin{array}{l}1.15 \\
1.13 \\
1.07 \\
1.19\end{array}$ & & 0.26 \\
\hline Density & $\begin{array}{l}\mathrm{A} \\
\mathrm{B} \\
\mathrm{C}\end{array}$ & & $\begin{array}{l}1453 \\
1238 \\
1507\end{array}$ & & $\begin{array}{l}3499 \\
3121 \\
6944\end{array}$ & & $\begin{array}{l}1507 \\
1292 \\
1184\end{array}$ & & 1550 \\
\hline (plants/hectare) & $\begin{array}{l}\text { Tempo- } \\
\text { raries }\end{array}$ & & 1829 & & 6027 & & 2422 & & 10979 \\
\hline
\end{tabular}


in the computation of the index (Table 3). The standard partial regression coefficients have been weighted $48.59 \%$ for cover, $17.9 \%$ for height, and $34.22 \%$ for density.

Production in Phase A for 1969 showed bitterbrush had produced only $22 \%$ of that recorded from the temporary exclosures $(8.2 \mathrm{~kg} / \mathrm{ha})$. The site could have potentially produced $37.8 \mathrm{~kg} / \mathrm{ha}$. Stagnation apparently accounted for a $78 \%$ reduction in production of the site potential in bitterbrush due to 5 years of protection from grazing. The sparse distribution of herbaceous species and the high variability of occurrence of the other shrub species among exclosure phases made analysis difficult.

An increase in precipitation during 1966 above that received in 1965 (a low precipitation year) brought a corresponding increase in yields. An even greater increase in precipitation during 1967 showed a proportionate increase in bitterbrush yields from the $\mathrm{B}$ and $\mathrm{C}$ phases. In contrast, Phase A not only produced less bitterbrush in 1967 than in the drier year of 1966 , but was also outproduced by both the $\mathrm{B}$ and $\mathrm{C}$ phases during 1967. suggesting that stagnation had occurred after 2 years of protection. The potential of this site is greater than any other site studied (Table 1). The site may produce as much as $426.3 \mathrm{~kg}$ of bitterbrush per hectare in a good year. Forage plants protected for annual utilization by wildlife and livestock exhibited stagnation, accounting for a sizable reduction in yield. Plants hand clipped 3 successive years to simulate $100 \%$ utilization of the annual growth produced over four times as much plant material as the plants protected from grazing for 5 years and then clipped to simulate the same $100 \%$ utilization.

Results suggest (Table 1) that present utilization of the area by livestock and deer is reducing bitterbrush production. Past and present use has reduced both the average height and number of individuals per hectare in the control area (Table 3 ).

\section{Fort Ruby}

Bitterbrush plants were few in numbers at this location (Table 3). Black sagebrush was the dominant shrub. Forage potential for grass species was generally low due to the high proportion of low volume producers such as Poa sandbergii.

The standard partial regression coefficients have been weighted $55.88 \%$ for the cover, $9.96 \%$ for the height, and $34.16 \%$ for the density of Artemisia nova based on the regression results (Table 2). Ten years of protection from the stimulus of grazing has accounted for a $65 \%$ reduction in site productivity in terms of black sagebrush production (Table 1). Results from the previous sites show that stagnation may have occurred within 2 to 3 years after protection.

Phase A produced $96.3 \mathrm{~kg} /$ ha of black sagebrush during the 1969 growing season but could have produced $270 \mathrm{~kg} / \mathrm{ha}$ of black sagebrush under similar treatment. Black sagebrush produced only $35 \%$ of its potential.

For rabbitbrush (Chrysothamnus viscidiflorus) the relative cover percentages of Phase A and the temporaries were $2.66 \%$ and $3.43 \%$, respectively. A comparison of yields shows 92 $\mathrm{kg} / \mathrm{ha}$ of rabbitbrush from the temporaries and $30.1 \mathrm{~kg} / \mathrm{ha}$ from Phase A. It is doubtful that a $1 \%$ greater canopy cover of rabbitbrush can account for almost a three-fold increase in yield. It appears that stagnation has occurred in this species, also. Observations during the collection of spring clippings confirmed deer utilization of rabbitbrush.

The response of grasses and forbs to continued protection from grazing was similar to that observed on other sites. Grass and forb cover in Phase A was only slightly higher than in the temporaries. Yet grass production in the completely protected area was approximately twice that recorded from the temporary exclosures in 1969. Forb yield is almost $100.9 \mathrm{~kg} / \mathrm{ha}$ in phase A as compared to $20.2 \mathrm{~kg} / \mathrm{ha}$ recorded from the temporaries.

The effect of continued heavy utilization on grass and forbs becomes apparent when yields from the temporary exclosures are compared to past yields recorded from the $\mathrm{B}$ and $\mathrm{C}$ phases subject to utilization by wildlife and livestock (Table 1). Protection for 1 growth season allowed a marked increase in vegetation production. The higher production of grasses and forbs in Phase A for 1969 is not explained by the data but may be due to the higher cover of forbs and slightly higher cover of grass (Table 3). Precipitation recorded at the exclosure site since 1965 shows that favorable growing conditions prevailed during the 1969 growing season. Results from the erection of temporary exclosures at this site provide evidence that continued protection from the stimulus of grazing has a strong influence on the shrubs. The data are not clear cut for the grass and forbs components and may be partially masked by the favorable growing conditions in 1969. Additional years would be required to determine whether stagnation occurs in grass and forb species.

\section{Discussion}

Utilization of the three-phase exclosure technique for rangeland evaluation is complicated by the responses of plants to nonuse. Garrison (1953) found shrubs unclipped and/or lightly clipped generally produced the least forage. Bitterbrush plants protected for 9 years produced $71 \%$ less than those that were browsed annually (Martinson 1960). Browsing tends to remove the apical bud resulting in an increase in twig numbers due to lateral branching. The initial imbalance in the shoot-root ratio due to severe removal of top growth creates an abundance of soil moisture and nutrients which favour new shoot growth (Ferguson and Basile 1966). Twig growth on spring-pruned mountain mahogany increased from less than $1 / 2$ inch annual growth before pruning to an average of 2.8 inches annual growth after pruning (Thompson 1970). Others have shown similar relationships with shrubs (Lyon 1966; Gibbens and Schultz 1962; Ferguson 1968). The utilization of course must be judicious. For example, removal of greater than $50 \%$ of the desert shrubs in late spring and summer for 3 years reduced yields, while $90 \%$ removal of current growth killed many of them (Cook 1971). However, browse production increased in many species including bitterbush, when 25 or $50 \%$ of the current year's growth was removed in fall or winter (Lay 1965).

This study has shown that nonuse in the fully protected area (Phase A) of an exclosure system causes vegetation stagnation of shrubs to occur as early as the second year after the exclosure is established. This condition was maintained for at least 8 years and, presumably, lasts indefinitely. Potential browse production in the A phase was reduced, depending on the site, from 3 to $78 \%$ of the average annual productivity of shrubs receiving the annual stimulus of browsing. Nonuse of bitterbrush resulted in an average reduction in productivity of $70 \%$. For big sagebrush the figure was $36 \%$.

Exclosure sites previously subjected to heavy utilization of grasses and forbs by livestock show that continued protection favors good growth and high yields of these species. Grass plants protected from grazing for several years produced up to $100 \%$ more vegetation than plants protected for only one growing season. The proper season and degree of use may be beneficial to be grazed grasses by increasing tillering, number 
of leaves and percent ground cover (Jameson 1963; Laude et al. 1968; Heady 1975, p. 19). In this study forb production was $20 \%$ higher in the fully protected areas than in the temporary exclosures. Stagnation exhibited by the shrub species probably contributed to the increased grass and forb yields by providing a release of moisture and nutrients to the forbs and grass. This is substantiated by the fact that basal area of grasses and forbs was the same in fully protected and the temporary exclosures. It must also be considered that grasses and forbs within the exclosures may be competing with the shrubs, thus contributing to the stagnation.

However, on some sites there is evidence to suggest that grass production, while higher in those areas protected for several years, is still lower than it might be with the annual stimulus of grazing. There is limited evidence that saliva from grazing animals adds thiamine to grasses and stimulates these plants to greater growth (Reardon et al. 1972). Grass plants inside phase A werc usually large with numerous culms, many of which were dead, giving them a much different appearance than the grazed plants. It appears that the plants were unthrifty due to the many dead culms.

The effect of stagnation in exclosures can be quite vivid. This is a noteworthy value of constructing such exclosures. Much useful information can be derived from exclosures by the agencies involved with range management if they are interpreted correctly. The stagnation effects on vegetation caused by lack of grazing are often not considered when exclosures are used for demonstration.

Some level of stagnation probably exists on any site that is not receiving at least a moderate degree of annual grazing or browsing. Data from this study indicate that stagnation is also evident in the portion of the exclosure systems utilized by deer only. Yield recorded under this condition would account for the fact that the control, or $\mathrm{C}$ phase of the exclosure site, produces more than the $B$ phases. This masking effect on yield serves as a great source of error in computing the relative utilization of forage by wildlife and livestock.

The three-phase exclosure technique can only be sensitive and supply reliable data in areas receiving moderate to heavy utilization (35-65\%) and only when used in conjunction with temporary movable exclosures so that reliable information on annual forage production can be obtained.

Large, profound year-to-year differences in production can be attributed to weather variation. Differences in forage productivity of up to 12 times from one year to the next have been measured (Tueller and Monroe 1975). These variations may supercede or mask the effects of stagnation, or at least make it extremely difficult to measure.

The corrections used in this study to adjust yield data from clipped plots have application in providing a more accurate method of measuring the degree of relative forge utilization from within the $\mathrm{B}$ and $\mathrm{C}$ phases of the three-phase exclosure system. Smith and Urness (1962) have pointed out that relative utilization figures alone, without some index of production, cannot indicate the pounds of forage utilized by either game or livestock. However, they do reflect the pressure exerted on the range. Production data obtained in this study in conjunction with information on food preferences provided by the exclosure system justify the use of such tools in rangeland evaluation.
Such exclosures may also serve as excellent training grounds for students.

\section{Literature Cited}

Cook, C.W. 1971. Effects of season and intensity of use on desert vegetation. Utah. Agr. Exp. Sta. Bull. 483. 57 p.

Daubenmire, R.F. 1940. Exclosure technique in ecology. Ecology 21:514515 .

Evans, A.E., and M.D. Jones. 1958. Plant height times ground cover versus clipped samples for estimating forage production. Agron. J. 50:504-506.

Ferguson, R.B. 1968. Survival and growth of young bitterbrush browsed by deer. J. Wildl. Manage. 32:769-772.

Ferguson, R.B., and J.V. Basile. 1966. Topping stimulates bitterbrush growth. J. Wildl. Manage. 30:839-841.

Frakes, R.V. 1959. Heritability estimates and genetic potential in alfalfa as affected by clipping treatments and stage of growth. Agron. Abstr. 45:241.

Garrison, G.A. 1953. Effects of clipping on some range shrubs. J. Range Manage. 6:309-317.

Gibhens, R.P., and A.M. Schultz. 1962. Manipulation of shruh form and browse production in game range improvement. California Fish and Game 48:49-64.

Harniss, R.O., and Robert B. Murray. 1976. Reducing bias in dry leaf weight estimates of big sagebrush. J. Range Manage. 29:430-432.

Heady, H.F. 1975. Rangeland Management. McGraw-Hill, New York. 460 p.

Jameson, D.A. 1963. Responses of individual plants to harvesting. Bot. Rev. 29:532-594.

Jones, W.B. 1965. Response of major plant species to elk and cattle grazing in northwestern Wyoming. J. Rangc Manage. 18:18-220.

Laude, Horton, M., Tuillermo Riveros, Alfred H. Murphy, and Robert E. Fox. 1968. Tillering at the reproductive stages in Hardinggrass. J. Range Manage. 21:148-151.

Lay, D.W. 1965. Effects of periodic clipping on yield of some common browse species. J. Range Manage. 18:181-184.

Lyon, J.L. 1966. Problems of habitat management for deer and elk in northern forests. Forest Service. U.S. Dept. of Agr. Intermountain Forest and Range Exp. Sta. Ogden, Utah. Res. Paper INT-24. 15 p.

Martinson, C.F. 1960. The effects of summer utilization of bitterbrush in north central Washington. M.S. Thesis, Univ. of Idaho, Moscow. 69 p.

McMahon, C.A. 1966. Suitability of grazing exclosures for deer and livestock research in the Kerr Wildlife Management Area, Texas. J. Wildlife Manage. 30:151-162.

Payne, Gene F. 1974. Cover-weight relationships. J. Range Manage. 27:403404.

Pasto, J.K., R.H. Allison, and J.B. Washko. 1957. Ground cover and height of sward as a means of estimating pasture production. Agron. J. 49:407409.

Poulton, C.E., and E.W. Tisdale. 1961. A quantitative method for the description and classification of range vegetation. J. Range Manage. 14:1321 .

Reppert, J.N., M.J. Morris, and C.A. Graham. 1962. Estimation of herbage on the California annual type. J. Range Manage. 15:318-323.

Smith, A.D., and P.J. Urness. 1962. Analysis of the twig length method of determining utilization of browse. Utah State Dep. Fish and Game Pub. No. 62-9. $36 \mathrm{p}$

Snedecor, G.W., and W.G. Cochran. 1967. Statistical Methods. Iowa State Univ. Press. Ames, Iowa. Sixth Edition. 593 p.

Young, S. 1955. Survey and evaluation of big game exclosures in Utah. MS Thesis. Utah State Agr. College. Logan. $70 \mathrm{p}$.

Young, S. 1958. Exclosures in big game management in Utah. J. Range Manage. 11:186-190.

Thompson, R.M. 1970. Experimental top pruning of curl leaf mahogany trees on the South Horn Mountains Ferron Ranger District-Manti-La Sal National Forest. Forest Service. U.S. Dep. Agr. Intermountain Region. Ogden, Uah. Range Improvement Notes 15(3):1-12.

Tueller, Paul T., and Leslie a. Monroe. 1975. Management guidelines for selected deer habitats in Nevada. Nevada Agr. Exp. Sta. Rep. R104. 185p.

Reardon, Patrick O., C.I. I einweber, and I.B. Merrill. 1972. The effect of bovine saliva on grasses. Proceedings, Western Section American Society of Animal Science. 23:206-210.

Uresk, D.W., Gilbert, and W.H. Richard. 1977. Sampling big sagebrush for phytomass. J. Range Manage. 30:311-314. 